\title{
DIREITO HOMOAFETIVO: A TUTELA CONSTITUCIONAL DOS DIRETOS HUMANOS SOB O PRINCÍPIO DA AFETIVIDADE
}

\section{HOMOAFETIVO LAW: CONSTITUTIONAL PROTECTION OF HUMAN DIRECT UNDER THE PRINCIPLE OF AFFECTIVITY}

${ }^{1}$ Lucas De Souza Lehfeld

${ }^{2}$ Marina Ribeiro Guimarães Mendonça

\section{RESUMO}

Sob o manto do princípio da afetividade, o artigo propõe uma análise da tutela constitucional dos direitos humanos ao tratar da equiparação jurídica nas consequências legais das relações homoafetivas. A lacuna legislativa, somada ao apelo ideológico, é tendenciosa ao preconceito e a discriminação, submetendo, assim, o grupo social, destacado pela adversidade sexual, ao distanciamento do acesso a direitos e garantias constitucionais que visam à proteção e o bemestar social. Prioriza, para tanto, a aplicabilidade do princípio da afetividade no tocante à interpretação constitucional, ações afirmativas ou a falta delas, e aos conflitos das garantias sociais fundamentais, nas discrepantes decisões jurídicas. $\mathrm{O}$ intuito é apreciar, perante a evolução jurisprudencial, o quanto direito e afeto são de extrema importância para a construção da igualdade social e consequente estruturação do Estado Democrático de Direito conforme preconiza a Magna Carta brasileira. Para tanto, a pesquisa foi desenvolvido a partir de revisão da literatura e jurisprudencial (pesquisa bibliográfica), bem como na utilização dos métodos lógico-dedutivo e indutivo.

Palavras-chave: Direitos humanos fundamentais, Homossexualismo, Principio da afetividade, Homoafetividade

\footnotetext{
${ }^{1}$ Doutorado em Direito pela Pontifícia Universidade Católica de São Paulo, PUC. São Paulo. SP, Brasil.

E-mail: indexlaw.ojs@ hotmail.com

${ }^{2}$ Graduação em Direito pela Faculdade de Direito de Franca, FDF, São Paulo. SP, Brasil.

E-mail: indexlaw.ojs@ hotmail.com
} 


\begin{abstract}
Under cover of the principle of affection, the article proposes an analysis of the constitutional protection of human rights when dealing with the legal equalization on the legal consequences of homo-affective relations. The legislative gap, coupled with the ideological appeal, is biased against prejudice and discrimination, submitting thus the social group, highlighted by sexual adversity, the distance from the access to constitutional rights and safeguards aimed at the protection and welfare. Priority, therefore, the applicability of the affection with regard to constitutional interpretation, affirmative action or lack thereof, and conflicts with basic social guarantees, in differing legal decisions. The aim is to assess, in the jurisprudential evolution, as right and affection are extremely important for building social equality and consequent structuring of the democratic rule of law as required by Brazilian Magna Carta. Therefore, the research was developed from literature review and case law (literature) as well as the use of logical-deductive and inductive methods.
\end{abstract}

Keywords/Palabras-claves/Mots-clés: Fundamental human rights, Homosexuality, Principle of affection. homoafetividade 


\section{INTRODUÇÃO}

Afeto e Direito. São institutos objeto de lutas e discussões calorosas quando se relacionam. Unidos, ademais, à diversidade sexual, proclamaram inúmeros avanços sociais e retrocessos sociais, pois a mesma sociedade que ovaciona a evolução jurídica do direito somados a afetividade e opção sexual, ainda é a mesma que adere a marginalização jurídica e social desse grupo.

O preconceito nitidamente impera nas situações que mesclam ideologia, religião, cultura e diversidade sexual, agravado, contudo, pela lacuna legislativa na realidade brasileira. Evidencia-se uma situação de vulnerabilidade que o grupo social pautado pela homossexualidade está imerso, mesmo com positiva evolução jurisprudencial e atividades constantes do Judiciário em pró ao alcance da justa aplicação da lei.

Consequentemente, buscou-se no Direito a segurança para as relações homossexuais por creditar ao Judiciário determinada influência na superação do preconceito e assim, consagrar a tutela das consequências jurídicas da união homoafetiva ao observar a importância do principio da afetividade no desenvolvimento legal dessas relações.

A negativa da regulamentação da matéria resulta em discrepância entre os julgadores que acabam por lesionar os Direitos Humanos Fundamentais (MORAES, 2011) dessa parcela de cidadãos. A marginalização legal também propicia um avanço negativo dos integrantes da sociedade em oprimir tais direitos tratando com desigualdade os homoafetivos, bem como, permitindo que as ações afirmativas percam força perante o preconceito social.

Para tanto, o presente estudo visa analisar o grupo social vulnerável e suas consequências jurídicas, de forma equidistante, na tentativa de compreender a Homoafetividade sob a ótica do Princípio da Afetividade, resultante do Princípio da Dignidade da Pessoa Humana, que é aclamado pela Constituição Federal de 1988 (Constituição Cidadã), principalmente ao estender o conceito de Família.

Devido ao viés jurídico atual, de lacuna legislativa, pertinente se faz o estudo sobre aspectos históricos culturais sobre a homossexualidade até a construção do protótipo de Direito Homoafetivo, analisando as jurisprudências atuais que pautam por consagrar o acesso aos Direitos Humanos Fundamentais cunhados no afeto. 


\section{O QUE É HOMOAFETIVIDADE? ASPECTOS HISTÓRICOS E CULTURAIS DO HOMOSSEXUALISMO}

O termo homoafetividade, assim estruturado por Maria Berenice Dias (2005), além de cada dia mais crescente na realidade mundial, principalmente por destacar a luta globalizada contra o preconceito e discriminação, traduz o sentimento constitucionalmente assegurado denominado afetividade. O neologismo homoafetividade é resultado da união das palavras homo, que quer dizer vários, e afeto, para então, traduzir as mais modernas relações humanas (DIAS, 2005).

Salientou a autora, ao escrever a primeira obra brasileira sobre o tema, que homoafetividade é a mais perfeita junção de Direito Civil com o Afeto. Nesse sentido, os relacionamentos que se comportarem de forma contínua e duradoura entre pessoas do mesmo sexo que constroem vida, sonhos, planos juntos com dedicação e esforço mútuos receberão o nome de relação homoafetiva (DIAS, 2005).

Porém, para se compreender o que vem a ser homoafetividade é necessário apreciar a evolução histórica cultural do homossexualismo no panorama brasileiro que vem consolidando seus efeitos jurídicos mesmo alheio a normatização.

No entanto, a crescente melhoria esbarra-se na sombra da homofobia que pode ser considerada como novo perigo para a negativa da dignidade humana devido a sua inserção direta com a moral e bons costumes como tônica social que afastam a afetividade.

\subsection{A evolução histórico-cultural do homossexualismo}

O homossexualismo existe desde a estruturação do que vem a ser sociedade e possui origem etimológica na Grécia Antiga época em que, naturalmente, a prática de se relacionar com o semelhante era aceita pela sociedade. Naquele período histórico fazia parte das obrigações do precipitado "servir de mulher" ao seu preceptor, e isso sob a justificativa de treiná-lo para as guerras, em que inexistia a presença de mulheres (DIAS, 2005).

e-ISSN: 2525-9849| Minas Gerais | v. 2 | n. 1 | p. 146 - 168 | Jan/Dez. 2015. 
Também se percebe a naturalidade de atos homossexuais nas Olimpíadas gregas, quando os atletas competiam nus, exibindo sua beleza física. $\mathrm{Na}$ ocasião, era vedada a presença de mulheres na arena. Para os homens, as mulheres não tinham capacidade para apreciar o belo.

Outra importante demonstração de homossexualismo aceito no seio social é referente às manifestações teatrais, em que os papéis femininos eram desempenhados por homens

acabam por resultar em pactos internacionais tal como o a Declaração Universal dos Direitos Humanos, na qual o Brasil é signatário, que são pautados em assegurar o Princípio da Dignidade da Pessoa Humana.

travestidos ou com o uso de máscaras (SULLIVAN, 1996). Portanto, era uma prática prevista e possível que apenas se restringia a não divulgar os atos que se relacionam com homossexualismo.

Qual, então, seria o marco histórico que culminou na imposição de repúdio ao envolver relação entre pessoas do mesmo sexo? O que impulsionou parcela da sociedade em atribuir obscenidade ao sentimento de afeto dessas relações? (MEDEIROS, 2014)

Muitos estudiosos da história do homossexualismo discorrem que tal repudio nasceu com a religiosidade e a ideia de moral que afastaram, assim, a afetividade das relações humanas homossexuais resultando até mesmo em crime de patologia na idade média. (GUINOSA, 2013). Compartilha desse pensamento Maria Berenice Dias (2009)

\begin{abstract}
A prática homossexual acompanha a história da humanidade e sempre foi aceita, havendo somente restrições à sua externalidade. Só passou a ser repudiada pela sociedade por influências de ordem religiosa. O maior preconceito contra a homossexualidade provém das religiões. A ideia sacralizada de família com fins exclusivamente procriativos levou à rejeição dos vínculos afetivos centrados muito mais do envolvimento mútuo. Toda relação sexual deveria tender à procriação. Daí a condenação da homossexualidade masculina por haver perda de sêmen, enquanto a homossexualidade feminina era considerada mera lascívia. A Igreja Católica, ao pregar que sexo se destina fundamentalmente à procriação, considera a relação homossexual uma aberração da natureza, uma transgressão à ordem natural, verdadeira perversão, baseada na filosofia natural de São Tomás de Aquino. (DIAS,2009. p 141-142)
\end{abstract}

A partir de então, a prática homossexual vem se colocando em posições às margens da sociedade e o preconceito e as injustiças tonam-se constantes. Pois, a mesma sociedade que luta por direitos ainda é a mesma que repudia a tutela desse grupo social na tentativa de 
afastar, impedir ou dificultar o acesso aos Direitos Humanos Fundamentais para uma sadia e digna condição de vida, como consagrados pela Constituição Cidadã.

Os avanços jurídicos são nítidos e a realidade atual também pode ser condensada por árduas lutas de grupos, ONGs, estudiosos, militantes da causa homossexual, englobando gays, transexuais, lésbicas, bissexuais e simpatizantes (GTLBS) na busca veemente da tutela jurídica para as consequências da união homoafetiva.

Ademais, pode-se atribuir, a essa crescente participação popular a globalização fazendo com que as lutas sejam compartilhadas por militantes de proporções continentais que

Os titulares desse grupo acentuam características peculiares ligadas a transformações sociais (lutas atemporais pelas garantias e direitos fundamentais). E, portanto, necessitam de toda atenção do Estado Democrático de Direito para que a tutela da dignidade humana jamais seja alvo de discrepância jurídica, marginalização legislativa, inacessibilidade de garantias e direitos, preconceito e discriminação.

A realidade atual ainda demostra que ao afastar a afetividade das relações homossexuais, a homofobia torna-se latente e de proporções capazes de comprometer garantias mínimas aos homossexuais, como a tutela a vida. 


\title{
2.2 O novo perigo ao bem-estar social: a Homofobia
}

A lacuna legislativa pode resultar em inúmeros percalços travando o desenvolvimento digno da sociedade. Esse é o pensamento expresso por inúmeros doutrinadores sobre a falta de leis em relação às consequências jurídicas das uniões homoafetivas.

Para eles, o preconceito e a discriminação que, nitidamente, violam a proteção do indivíduo, principalmente das minorias em que são mais vulneráveis, não encontra, nesse caso, barreiras ou sanções jurídicas atuantes para conter o avanço da homofobia. Entendem que se atribui ao Direito, e seu caráter organizacional, estipular sanções para as condutas ofensivas ao indivíduo.

\begin{abstract}
As leis servem de norte de como as pessoas devem agir. Criam pautas de conduta, modelos de comportamentos que irão reger a vida em sociedade. Este é o significado maior da atividade legiferante. Mas o sistema legal precisa contemplar todos os segmentos sociais, não só os que são compostos por um número maior de cidadãos. Como as minorias são mais vulneráveis, precisam da especial proteção do Estado. Sem uma atenção diferenciada tornam-se alvo da rejeição por parte da maioria. Por isso é indispensável a adoção das chamadas ações afirmativas (DIAS, 20005.p 10).
\end{abstract}

Mesmo que a Constituição Federal atribua às famílias brasileiras sua base calcada na afetividade, e não houve estipulação no texto constitucional sobre a forma como essas famílias se constituem, se homoafetivas ou não, parcela da sociedade repudia e afasta a compreensão do afeto ao negar a existência de uniões homoafetivas pela ausência do termo no texto constitucional.

Tal pratica foi denominada Homofobia. Borillo (2009, p.49) aponta a homofobia como "fenômeno social e manifestação do sexismo, traduzindo-se em hostilidade a comportamentos desviantes dos papéis sócio-sexuais estabelecidos e guardando íntima relação com violência de gênero".

A realidade que se verifica nos jornais e estatísticas de violência contra homossexuais no Brasil confirma o entendimento acima de que há necessidade de composição legal para que a sociedade compreenda que respeito à dignidade da pessoa humana deve 
prevalecer sobre qualquer dilema, principalmente, sobre a moral, com intuito de evitar atrocidades e abusos aos direitos fundamentais.

Maria Berenice Dias (2010) entende que prevalece ainda na sociedade a primazia da moral e dos bons costumes gerando a exclusão, o preconceito e a discriminação dos homossexuais.

\begin{abstract}
Apesar de todos os dogmas, princípios e regras, que buscam assegurar a primazia dos direitos humanos, a sociedade, em nome da preservação da moral e dos bons costumes, impõe padrões de comportamento restritos. Com seu perfil nitidamente conservador, cultua valores absolutamente estigmatizantes, insistindo em repetir o modelo posto. Tal postura gera um sistema de exclusões baseado muitas vezes em meros preconceitos. Tudo o que se situa fora do estereótipo acaba sendo rotulado de “anormal”, ou seja, fora da normalidade. O que não se encaixa nos padrões aceitos pela maioria é apontado como uma afronta à moral e aos bons costumes. Essa visão polarizada é extremamente limitante (DIAS, 2010 p.3)
\end{abstract}

Na visão da autora, a lei, portanto, seria uma maior segurança possível para proteção dos direitos e injustiças cunhados aos homossexuais por ainda se submeterem a preceitos de moral. Pois, as mudanças de paradigmas devem ser revistas conforme a necessidade de cada sociedade visando sempre o bem comum, como preconiza o Estado Democrático de Direito.

E em se tratando de relações homoafetivas, a coerção por meio de lei seria essencial para se fazer cumprir os preceitos constitucionais fundamentais, entre eles, a igualdade e liberdade afastando a homofobia do integro social.

O posicionamento de Maria Berenice Dias pode ser estruturado em dados da Secretaria de Direitos Humanos da Presidência da República que lançou o "relatório sobre a violência homofóbica no Brasil" e afirmou que as ações dessa natureza são constantes afastando a cidadania e seguridade dos Direitos Humanos (DIAS, 2010).

A homofobia no Brasil é estrutural e com esse cenário negativo, a construção do Direito Homoafetivo torna-se cada dia mais imprescindível com finalidade norteadora do fortalecimento da cidadania ao assegurar os direitos humanos fundamentais para esse vulnerável grupo, não só social, como jurídico (MOTT, 1997)

As relações homoafetivas imperam, mesmo com tamanhas divergências em meio ao cenário homofóbico. Busca-se, para tanto, a tutela aos efeitos jurídicos da união homoafetiva 


\subsection{A Dignidade humana da igualdade}

O art. $1^{\circ}$ da Constituição Federal de 1988 trata dos fundamentos da República Federativa do Brasil na busca ao bem-estar social e proteção digna da sociedade. Para tanto, a figura do Estado Democrático de Direito faz-se de suma importância para aplicabilidade desses fundamentos, pois, a dignidade humana, que é premissa antropológica-cultural da soberania popular e divisão de poderes, pelos direitos fundamentais e tolerância, pela pluralidade de partidos e a independência dos tribunais, é inerente do Estado Constitucional e somente possui tais características por primar do Democrático de Direito (HARBELE, 1997).

Conforme acentua Nery (2013), o Estado Constitucional impõe o sentido da dimensão dos direitos fundamentais e a proteção da dignidade humana constitui-se em seu dever fundamental (dever jurídico-fundamental), ademais, dignidade humana constitui a norma fundamental do Estado e é premissa para todas as questões jurídico-dogmáticas particulares.

Nos dizeres do autor, "é mais que isso: ela fundamenta também a sociedade constituída e eventualmente a ser constituída. Ela gera uma força protetiva pluridimensional, de acordo com a situação de perigo que ameaça os bens jurídicos de estatura constitucional" (NERY, 2013, p.220), confirmando a extrema importância do Principio da Dignidade da Pessoa Humana para assegurar a acessibilidade das garantias e direitos fundamentais e afastar a ameaça à marginalização social e jurídica dos grupos sociais suscetíveis à vulnerabilidade ou os taxados de minoria.

Conclui Alexandre Moraes (2011) que a previsão dos direitos humanos fundamentais direciona-se basicamente para a proteção à Dignidade Humana em seu sentido mais amplo. Ou seja, a constitucionalização dos direitos humanos fundamentais não significou mera enunciação formal de princípios, mas sim a plena positivação de direitos, a partir dos quais quaisquer indivíduos poderão exigir sua tutela perante o Poder Judiciário para a concretização da democracia.

A jurisprudência atual segue o mesmo entendimento, conforme decisão do Ministro 
Celso De Mello no HC 85988/PA, em 10 de junho 2005,

[...] a dignidade da pessoa humana é principio central do sistema jurídico, sendo significativo vetor interpretativo, verdadeiro valor-fonte que conforma e inspira todo o ordenamento constitucional vigente em nosso país e que traduz, de modo expressivo, um dos fundamentos em que se assenta, entre nós, a ordem republicana e democrática consagrada pelo sistema de direito constitucional positivo (NERY, 2013. P 225)

Sob esse enfoque, é nítida a necessidade de proteção aos direitos humanos fundamentais de grupos sociais tendentes a exclusão de direitos e marginalização legal e social como o disposto no trabalho. Cabe, portanto, ao Estado, o dever de criar as condições para levar isso (dignidade humana) a cabo, de tal sorte que a dignidade humana não seja violada por terceiros (integrantes da sociedade). (HARBELE, 1997).

Pois, para se construir o Estado Democrático de Direito é imprescindível assegurar tal proteção jurídica. Sem respeito à pessoa humana não há justiça e sem justiça não há Direito. (FRANCO, 1958). Portanto, a busca a efetivação desses princípios é complexa e carregada de sentimento apaixonado. Os titulares desse direito estão emersos em justiça e preconceito que são ingredientes ligados as mais calorosas discussões políticas e jurídicas.

O grupo social pautado na homoafetividade, de alguma forma, possui peculiaridades que o coloca em condições de desigualdade jurídica e social e, consequente discriminação e preconceito. Os fatores são diversos, porém, a premissa da igualdade é apenas uma: todos são iguais perante a lei.

A partir dessa premissa, a igualdade impera sobre a moral e bons costumes fazendo valer toda proteção constitucional e digna do ser humano, independente de raça, idade, opção sexual, crença, deficiência ou qualquer outro fator que tendesse a marginalizar um integrante da sociedade.

Nesse sentido, nem mesmo o legislador e interprete (autoridade publica) poderiam atuar de forma diversa ao que assegura o principio da igualdade seguindo, também, tal entendimento o particular. 
O legislador, no exercício de sua função constitucional de edição normativa não poderá afastar-se do principio da igualdade, sob pena de flagrante inconstitucionalidade. Assim, normas que criem diferenciações abusivas, arbitrarias, sem qualquer finalidade licita, serão incompatíveis com a Constituição Federal.

O interprete-autoridade publica não poderá aplicar leis e atos normais aos casos concretos de forma a criar ou aumentar desigualdades arbitrarias. Ressalta-se que, em especial o poder judiciário, no exercício de sua função jurisdicional de dizer o direito ao caso concreto, deverá utilizar mecanismos constitucionais no sentido de dar uma interpretação única e igualitária as normas jurídicas. No tocante ao particular, "não poderá pautar-se por condutas discriminatórias, preconceituosas ou racistas, sob pena de responsabilidade civil e penal, nos termos da legislação em vigor. (MORAES, 2011. p. 3).

No entendimento de Alexandre de Moraes, o que a Constituição federal demostra, com a igualdade do artigo $5^{\circ}$, é na verdade a vedação de diferenças arbitrárias com discriminações absurdas (MOARES, 2013).

Nesse mesmo sentido coaduna Fabio Konder Comparato (1996) ao compreender que a finalidade das liberdades materiais tem por objetivo a igualdade de condições sociais, meta a ser alcançada não só por meio de leis, mas também pela aplicação de politicas públicas ou programas de ações governamentais.

E por isso, torna-se a igualdade tão valiosa para a tutela dos efeitos jurídicos nas uniões homoafetivas. Ademais, a igualdade deve ser verificada em dois planos: frente ao legislador e executivo e outra frente ao interprete. Como bem salienta Alexandre de Moraes: Também, verifica-se a aplicabilidade desse principio na jurisprudência atual. É o que se segue:

TRF $4^{\circ}$ Região - A realidade social atual revela a existência de pessoas do mesmo sexo convivendo na condição de companheiros, como se casados fossem. 2 . O vácuo normativo não pode ser considerado obstáculo intransponível para o reconhecimento de uma relação jurídica emergente de fato público e notório . 3. O princípio da igualdade consagrado na Constituição Federal de 1988, inscrito nos artigos $3^{\circ}$, IV, e $5^{\circ}$, aboliram definitivamente qualquer forma de discriminação. 4. A evolução do direito deve acompanhar as transformações sociais, a partir de casos concretos que configurem novas realidades nas relações interpessoais. (TRF $4^{\mathrm{a}}$ Região, AC 349785, j. 21/11/2000).

A dignidade humana deve ser apreciada rigorosamente nas tutelas jurídicas das uniões homoafetivas. Nesse sentido, a igualdade será a consequência prevista na atuação do 
Poder Judiciário e ações afirmativas do Poder Público perante a lacuna legislativa para concretizar os direitos humanos fundamentais. Assim, a tutela jurídica das uniões homoafetivas vislumbrarão a possibilidade de pautar as consequências da união na afetividade assegurando todos os direitos de uma relação familiar, de forma igualitária.

\subsection{A Afetividade}

O Direito também possui premissa à busca da felicidade. Nesse sentido, compreendese um salto normativo na proibição do preconceito para a proclamação do direito a liberdade sexual. Por esse prisma, o afeto traduz-se importante para assegurar o direito à autonomia da vontade quanto à sexualidade e sucessivamente o direito subjetivo de constituir família pautado na felicidade dos cidadãos como direito fundamental ao bem-estar social. (NERY, 2013).

O Código Civil reconhece, no art. 1.593, outras espécies de parentesco civil além daquele decorrente da adoção, acolhendo, assim, a noção de que há também parentesco civil no vínculo parental proveniente quer das técnicas de reprodução assistida heteróloga relativamente ao pai (ou mãe), que não contribuiu com seu material fecundante, quer da paternidade socioafetiva, fundada na posse do estado de filho. A partir de então, o Direito Civil vê a afetividade de forma continua e primordial nas relações de família, como se percebe na III Jornada de Direito Civil, que ocorreu em dezembro de 2004, ao retratar no Enunciado $n^{\circ} 256$, "A posse de estado de filho (parentalidade socioafetiva) constitui modalidade de parentesco civil. (NERY, 2013, p. 919)

A jurisprudência brasileira passa a aplicar o princípio da afetividade, com a predominância na concretização de "família".

O que deve balizar o conceito de "família" é, sobretudo, o princípio da afetividade, que "fundamenta o direito de família na estabilidade das relações socioafetivas e na comunhão de vida, com primazia sobre as considerações de caráter patrimonial ou biológico". (STJ, Recurso Especial n. 945283/RN, 4ª T., Rel. Min. Luiz Felipe Salomão, DJ 15.09.2009, DJe. 28.09.2009).

Portanto, a afetividade é o principio norteador do direito de família e assim, a família homoafetiva está cunhada de direitos e garantias constitucionais, bem como todas as famílias antes margeadas à lei. Pois, a luta pela inclusão da afetividade, consagrada pelo principio 
constitucional da Dignidade da Pessoa Humana, ventou nas relações homossexuais de que elas também seriam famílias e, portanto, passíveis de direitos e deveres como o casamento e a união estável. Surge, nesse cenário de contemplação da felicidade, a "família homoafetiva".

\section{A HOMOAFETIVIDADE E A FAMÍLIA}

A promulgação da Constituição Federal de 1988 trouxe inovações no tocante às características fundamentais, esparsas pelo texto constitucional. Nesse contexto, as famílias ganham novos formatos e direitos ao receber influxo do Direito Constitucional àquelas que se formaram as margens do casamento (extramatrimoniais).

Assim, a legislação ampliou o conceito de família para além da instituição casamento, demostrando nítido avanço constitucional. Marco Túlio de Carvalho Rocha (2009) compactua com a consagração dos princípios fundamentais pela Constituição de 1988 na extensão ao conceito de família, para ele,

\footnotetext{
No Brasil, embora os novos princípios tenham ganhado espaço, paulatinamente, durante todo o século XX, a Constituição da República de 1988 é o marco dessas transformações, por ter consagrado a igualdade dos cônjuges e a dos filhos, a primazia dos interesses da criança e do adolescente, além de ter reconhecido, expressamente, formas de famílias não fundadas no casamento, às quais estendeu a proteção do Estado (ROCHA, 2009, p. 10).
}

O artigo 226 da Constituição Federal de 1988 pluralizou o conceito de família e seus efeitos. Expressa Nery (2013, p. 919) que a "isonomia entre casais heteroafetivos e pares homoafetivos que somente ganha plenitude de sentido se desembocar no igual direito subjetivo à formação de uma autonomizada família”.

E é exatamente nessa proteção jurídica que se pautam as relações homossexuais sabidamente ao entender que o Estado não poderia realizar distinção ofendendo o princípio constitucional da igualdade ao fazer diferença de pessoas quanto ao sexo até mesmo por ser a instituição família anterior ao Direito.

Assim, as Uniões Homossexuais se constituem de direitos, tais como da personalidade, patrimoniais, civil, família entre outros e, portanto, merecem a tutela jurídica mesmo que a sociedade impute preconceito ou que não haja expressamente delimitado a relação entre pessoas do mesmo sexo pela Constituição e legislação infraconstitucional. 
Como adverte João Baptista Villela (1979, p. 416): "Sexo é sexo, patrimônio é patrimônio. Se, em geral, já é um princípio de sabedoria e prudência não misturá-los, aqui é definitivamente certo que um nada tem a ver com o outro". Assim, busca-se compreender a importância da tutela jurídica das uniões homoafetivas perante a realidade crescente de injustiças sociais e jurídicas para esse grupo de minorias.

Mesmo com tanto avanço social, apenas em 2011 é que o Supremo Tribunal Federal equiparou as relações homossexuais às uniões estáveis no julgamento da Ação Direta de Inconstitucionalidade (ADI) n. 4.277, e a Arguição de Descumprimento de Preceito Fundamental (ADPF) n. 132.

Na ocasião, os ministros do Supremo Tribunal Federal reconheceram o direito da união contínua, pública e duradoura entre pessoas do mesmo sexo como "entidade familiar" equiparando, portanto, direitos e deveres legais constantes em uma união de pessoas.

Ocorre o reconhecimento da união homoafetiva pelo STF que foi toda pautada na afetividade inserida no conceito atual de família e, por consequência, assegurando a Dignidade da Pessoa Humana conclamada na Constituição. Os ministros argumentaram que a interpretação do conceito de família não poderia ser reducionista de direitos devendo pautar também as famílias concebidas alheias às vias do casamento civil.

Para eles, o questionamento realizou-se no âmbito da caracterização da família quanto ao seu afeto. O Ministro Luiz Fux relatou que não são os laços sanguíneos que fazer uma família, pois, "os cônjuges ou companheiros não os têm entre si e, mesmo sem filhos, podem ser uma família; entre pais e filhos adotivos também não os haverá. De igual modo, a coabitação não será necessariamente um requisito - uma família se desintegra, por exemplo, um filho vai estudar no exterior? É claro que não" (STF, 2011).

Nesse sentido, pode-se concluir que a decisão do Supremo Tribunal Federal expressou a quarta família brasileira. Perante a Constituição e seus princípios, declarados principalmente pelo principio da igualdade, era possível verificar três constituições de família: a decorrente do casamento, a família formada com a união estável e a entidade familiar monoparental (apenas um cuida do filho). E, agora, a decorrente da união homoafetiva, reconhecida pelo STF, que pode ser conclamada como entidade familiar homoparental (em que há multiplicidade de pais vinculados ao filho). (FARO; PESSANHA, 2014) 


\section{DIREITO HOMOAFETIVO E OS EFEITOS JURÍDICOS DA UNIÃO HOMO- AFETIVA}

O tópico refere-se à aplicação dos princípios já estudados, bem como a evolução do homossexualismo perante a afetividade, nas decisões jurídicas mais importantes sobre homoafetividade a fim de estruturar o Direito Homoafetivo.

O intuito é observar as consequências jurídicas sobre a União Homoafetiva sob o viés de união estável e casamento. Na concepção de família, interpreta as principais decisões sobre homoparentalidade, adoção e reprodução assistida. Em relação às consequências sociais, verifica as recentes decisões sobre pensão, partilha, guarda de filhos, entre outras consequências do contrato civil relacionados ao matrimonio.

\subsection{A equiparação Jurídica: casamento e união estável na homoafetividade}

Mesmo que com evidente atraso legislativo, em 2009, pode-se perceber a movimentação do poder jurídico ao julgar o reconhecimento da união homossexual. Nesse mesmo ano, nove estados e o Distrito Federal tomaram a mesma atitude. Em cinco de maio de 2011, o STF reconhece através de duas ações diretas de constitucionalidade os mesmos direitos assegurados a união estável aos casais homoafetivos e extrai-se dos julgados o pensamento de que o reconhecimento consagrado nas decisões permite a utilização das mesmas regras de normatização das relações heteroafetivas.

\footnotetext{
Contudo, pode-se perceber que o judiciário está acompanhando as lutas sociais pela tutela dos direitos e efeitos jurídicos da União Homoafetiva na tentativa de se consolidar os princípios constitucionais. Assim, ao equiparar a união estável a união homoafetiva, em 2011, o STF aplicou a teoria do direito fundamental, principalmente, pautado pelo fundamento da republica da Dignidade da Pessoa Humana por reconhecer, ante a qualquer dilema imposto, a preferencia sexual como direito emanação do principio da dignidade da pessoa humana (NERY, 2013, p. 920).
}

Devido à falta de legislação e as controvertidas decisões a respeito dos efeitos 
jurídicos da união homoafetiva, o estudo inicia sua análise a partir do julgamento de 2011 do STF que resultou favoravelmente na equiparação de união homoafetiva a de união estável entre homens e mulheres e, por consequência, abarcou inúmeros direitos a eos efeitos jurídicos dessa relação.

Cada ministro abordou aspectos distintos para seus posicionamentos, porém, a temática central foi a afetividade no conceito de família que norteou os votos e seu resultado. No entanto, como bem preceituou o Ministro Peluso, ao confirmar seu posicionamento, que sobre a união homoafetiva deve-se ater a detalhes como a equiparação a união estável e, portanto, aplicaria apenas as normas vigentes do Direito de Família em relação a esse tipo de união.

Mas nem todas, disse o Presidente do Supremo, por não se tratarem de uniões idênticas, reafirmando o pensamento sobre a equiparação (SARMENTO, 2011). O Ministro ainda advertiu uma preocupação quanto a falta de legislação pertinente a equiparação das uniões estáveis e homoafetivas e instiga o Congresso Nacional a viabilizar tal procedimento regulamentar.

Sob esse aspecto, de lacuna na legislação, é que se deve analisar e elencar alguns direitos tutelados após a apreciação da Ação Direta de Inconstitucionalidade (ADI) nº4277, ajuizada pela Procuradoria-Geral da Republica e a Arguição de Descumprimento de Preceito Fundamental (ADPF) 132, ajuizada pelo Governo do rio de Janeiro. A ADI 4277 pedia declaração de reconhecimento da união entre pessoas do mesmo sexo como entidade familiar (FARO; PESSANHA, 2014).

Requeria ainda que os mesmos direitos e deveres dos companheiros nas uniões estáveis fossem estendidos aos companheiros nas uniões entre pessoas do mesmo sexo. Já na Arguição de Descumprimento de Preceito Fundamental (ADPF) 132, o governo do Estado do Rio de Janeiro alegou que o não reconhecimento da união homoafetiva contraria preceitos fundamentais como igualdade, liberdade (da qual decorre a autonomia da vontade) e o princípio da dignidade da pessoa humana, todos da Constituição Federal. (FARO; PESSANHA, 2014).

Com esse argumento, pediu ao STF que aplicasse o regime jurídico das uniões estáveis, previsto no artigo 1.723 do Código Civil, às uniões homoafetivas de funcionários 
públicos civis daquele Estado.

Importante destacar o formato dessa apreciação, pois, dela surgiram outras conceituações relevantes com consequências jurídicas em temas como adoção e garantias sociais, oportunamente abordadas. Na ocasião, os ministros do Supremo Tribunal Federal votaram de forma unanime os pedidos incitados. Em relação ao efeito vinculante da decisão é que se percebeu a complexidade do tema.

Pois, parte do ministros acompanharam o voto do relatos Ayres Britto sobre a positividade do efeito vinculante. Seguiram seu pensamento os Ministros Luiz Fux, Ricardo Lewandowski, Joaquim Barbosa, Gilmar Mendes, Marco Aurélio, Celso de Mello e Cezar Peluso, Carmem Lúcia Antunes Rocha e Ellen Gracie. No entanto, Ricardo Lewandowski, Administração Publica apliquem a mesma interpretação afastando o pressuposto de diferenciação dos direitos devido a diversidade sexual.

Devem vincular-se a decisão do STF e colocar em pratica as facilitações ao reconhecimento dos efeitos jurídicos dessas uniões. No julgamento que começou no dia 4 de maio, assegurou-se, primeiramente, que o que impera no art. 1723 do Código Civil relacionado a interpretação em conformidade com a Constituição Federal de 1988, que será atribuído as uniões homoafetivas afastando, ainda, qualquer forma de discriminação ou impedimento de reconhecimento desses direitos aos relacionamentos homossexuais (FARO; PESSANHA, 2014).

Às ações foram atribuídos os efeitos vinculantes e com as mesmas regras e consequências da união entre pessoas do mesmo sexo. Conforme conclui Nery (2013, p.920), “isso para excluir do dispositivo em causa qualquer significado do que impeça o reconhecimento da união continua, pública e duradoura entre pessoas do mesmo sexo como família".

Muitos estudiosos creditam a decisão do STF como um marco histórico por reconhecer a união estável entre pessoas do mesmo sexo. Ressaltam, ademais, que existem dois grandes motivos para a evolução jurídica do julgamento: o papel do STF como constituinte derivado e o enquadramento da união homoafetiva como um tipo de entidade familiar (FARO; PESSANHA, 2014). 
O primeiro é o fato de que a legislação infraconstitucional possuía um dispositivo idêntico a uma previsão constitucional; o que atesta a existência de algo maior que uma simples interpretação conforme a Constituição, tendo o STF feito o papel de constituinte derivado, embora não tenha tal legitimidade. Nos casos (ADI 4277 e ADPF 132) decididos, a pretensão era pela aplicação do regime jurídico da união estável entre pessoas de diferentes sexos às uniões entre pessoas do mesmo sexo. A decisão do STF, que tem eficácia erga omnes e efeito vinculante para a Administração Pública e os demais órgãos do Judiciário, foi confirmada em outro julgado do próprio STF (AgR-RE 477554), onde reafirmou que a união estável homoafetiva é um tipo de entidade familiar. (FARO; PESSANHA, 2014).

No julgamento, outra importante discussão pairou sobre a equiparação da união estável entre casais homoafetivos. Seria possível que essa equiparação também alcançasse o pública, duradoura e contínua baseada no afeto entre as pessoas. Portanto, o entendimento adotado pelo STF desde 2011 não se restringiu às uniões estáveis indo além, tornando possível o casamento homoafetivo, seja mediante a conversão da união estável, seja mediante o casamento direto. (FARO; PESSANHA, 2014).

Coaduna com o mesmo sentimento o STJ ao decidir, no Recurso Especial n. 1183378, de origem do Rio Grande do Sul, em 2011, que haveria sim a possibilidade de casamento entre pessoas do mesmo sexo sem qualquer repudio ou vedação de legislação. Também pautou seu julgamento na entidade familiar como poliformismo familiar.

Inaugura-se com a Constituição Federal de 1988 uma nova fase do direito de família e, consequentemente, do casamento, baseada na adoção de um explícito poliformismo familiar em que arranjos multifacetados são igualmente aptos a constituir esse núcleo doméstico chamado "família", recebendo todos eles a "especial proteção do Estado". Assim, é bem de ver que, em 1988, não houve uma recepção constitucional do conceito histórico de casamento, sempre considerado como via única para a constituição de família e, por vezes, um ambiente de subversão dos ora consagrados princípios da igualdade e da dignidade da pessoa humana. Agora, a concepção constitucional do casamento diferentemente do que ocorria com os diplomas superados deve ser necessariamente plural, porque plurais também são as famílias e, ademais, não é ele, o casamento, o destinatário final da proteção do Estado, mas apenas o intermediário de um propósito maior, que é a proteção da pessoa humana em sua inalienável dignidade. O pluralismo familiar engendrado pela Constituição - explicitamente reconhecido em precedentes tanto desta Corte quanto do STF - impede se pretenda afirmar que as famílias formadas por pares homoafetivos sejam menos dignas de proteção do Estado, se comparadas com aquelas apoiadas na tradição e formadas por casais heteroafetivos. $\mathrm{O}$ que importa agora, sob a égide da Carta de 1988, é que essas famílias multiformes recebam efetivamente a "especial proteção do Estado", e é tão somente em razão desse desígnio de especial proteção que a lei deve facilitar a conversão da união estável em casamento, ciente o constituinte que, pelo casamento, o Estado melhor protege esse núcleo doméstico chamado família. (FARO; PESSANHA, 2014). 
A partir de tal evolução jurisprudencial sobre a equiparação da união homoafetiva ao casamento e crescentes discordâncias jurídicas sobre o assunto, o Conselho Nacional de Justiça (CNJ) editou, no ano de 2013, a Resolução n.175 que proíbe as autoridades competentes se recusassem a habilitar, celebrar casamentos civis ou converter união estável em casamento entre pessoas do mesmo sexo. O que chama a atenção é o fato de o CNJ não ser órgão legislativo e ainda fixar na Resolução n. 175 que o interessado pode comunicar a recusa ao juiz corregedor competente para que as providências cabíveis sejam tomadas (FARO; PESSANHA, 2014).

Alguns autores concluem, portanto, que não se pode impedir o casamento entre pessoas do mesmo sexo por ferir preceitos constitucionais. Ademais, a equiparação pauta-se na afetividade e o que realmente importa no reconhecimento do casamento são seus efeitos jurídicos, pois, como não há no ordenamento jurídico brasileiro normatização para a equiparação entre o que vem a ser companheiro e cônjuge, de forma direta, apega-se as diferenciações jurídicas entre a formalidade da união estável e o casamento no intuito de garantir os direitos inerentes aos efeitos dessa relação seja ele homoafetiva ou heteroafetiva no intuito de preservar e garantir os preceitos constitucionais dos direitos fundamentais (FARO; PESSANHA, 2014)

Coube, contudo, à Vara de família fazer o reconhecimento de tais demandas, conforme o Recurso Especial n. 820475-RJ (Superior Tribuna de Justiça (STJ). $4^{\text {a }}$ T. Rel. Min. Antonio de Padua Ribeiro, j 2.9.2008), ao reconhecer que "o direito brasileiro não proíbe a ação objetivando o reconhecimento de união estável entre pessoas do mesmo sexo, o pedido é juridicamente possível e preenche os requisitos do CPC, art. 267, VI, devendo a ação ser julgada em vara de família” (NERY, 2013.p 921)

Após anos de luta e organização de estudiosos, grupos sociais, Poder Judiciário sobre o levante de união estável e casamento homoafetivos, em 2015, percebe-se a evolução do tema ao ser noticiado o primeiro divorcio homoafetivo do Brasil. Situações envolvendo divórcio de casais homoafetivos ainda são tratados com sigilo pelas partes e seus advogados, portanto, o caso ocorreu há dois anos e somente em 2015 foi anunciado. 
Evidencia-se, porém, a evolução do Poder Judiciário em buscar a tutela aos Direitos Humanos Fundamentais do grupo social pautado pela diversidade sexual e cunhado de tantas peculiaridades. Apesar de inúmeras divergências jurídicas e falta de normatização, a busca pela felicidade consagrada na afetividade das uniões homoafetivas sob a prerrogativa de família, prioriza, conclusivamente a concretização do principio da Dignidade da pessoa humana e a construção efetiva do Estado Democrático de Direito. 6 CONCLUSÃO

O vinculo afetivo acompanha a história e é alvo constante de quebra de paradigmas que transformam os ideais de uma sociedade. Hoje, pode-se observar o vinculo afetivo no conceito estendido da entidade familiar que a Constituição Federal de 1988 assegurou efetivamente no corpo de seu texto, principalmente, por pautar seus objetivos e fundamentos no bem-estar social e assim, garantir o acesso aos Direitos Humanos Fundamentais a todos os cidadãos brasileiros.

No contexto histórico, a luta pelas garantias sociais conclamadas pela afetividade e sua positivação possui datas importantes, tais como a promulgação da Constituição do México em 5 de fevereiro de 1917, a Declaração dos direitos do povo trabalhador e explorador redigida no âmbito da Revolução russa de 1917 (promulgada em 3 de janeiro de 1918) que trouxe algumas inovações acentuadas, posteriormente, pela primeira constituição soviética de 10 de julho de 1918.

Talvez, o marco histórico mais famoso de promulgações constitucionais de direitos humanos fundamentais seja a promulgação da primeira constituição alemã, devido à contextualização a que foi inserida. No fim da Primeira Guerra Mundial a Constituição de Weimar foi considerada pelos historiadores um compromisso ou pacto social firmado entre burguesia e as demais forças sociopolíticas existentes a época. Fez surgir assim, a positivação dos direitos humanos fundamentais de diversas naturezas, entre ela, o afeto.

A particularidade quanto a ser a mais famosa promulgação deve-se a violação desses tão almejados direitos sociais por Adolf Hitler. Indiscutivelmente, o então comandante nazista violou a democracia do país e cometeu atos de notória atrocidade a dignidade humana, ainda, dignos de revolta.

De lá para cá, a sociedade se transformou, e os direitos sociais evoluíram com as gerações. No entanto, por mais globalizado que sejam os direitos humanos fundamentais, consagrados histórico, social e culturalmente pelos ordenamentos jurídicos continentais, a violação, a 
marginalização e a defasagem de ações afirmativas imperam sobre a realidade brasileira no que se refere a grupos de minorias e vulneráveis, principalmente, quando

validar suas decisões em um país ainda com lacunas jurídicas imprecisas e gritante homofabia. A afetividade, portanto, é o caminho para a construção do efetivo Estado Democrático de Direito.

\section{REFERÊNCIAS}

ALMEIDA, Maria Cristina de. DNA e estado de filiação à luz da dignidade humana. Porto Alegre: Livraria do Advogado, 2003.

BALESTRINI, Patrícia Eli. A conversão das uniões homoafetivas em casamento e suas consequências jurídicas. Disponivel em:

<http://www.direitohomoafetivo.com.br/anexos/trabalho_tese/23_f0f6a03498a57c5402009a 751307971a.pdf>. Acesso em: 25 mar. 2015.

BOSWELL, John. Christianity, Social Tolerance and Homosexuality. Gay People in Western Europe from the Beginning of the Christian Era to the Fourteenth Century. Chicago/London: University of Chicago Press, 1980.

COMPARATO, Fabio Konder. Direito publico: estudos e pareceres. São Paulo: Saraiva, 1996.

CANOTILHO, J.J. Gomes. Direito constitucional. Coimbra: Almedina, 1993.

DIAS, Maria Berenice. Manual de direito das famílias. São Paulo: Revista dos Tribunais, 2009.

União Homoafetival, o Preconceito e a Justiça. 4. ed. São Paulo: Editora Revista dos Tribunais, 2009.

A democratização do casamento. Disponível em:

<http://www.ibdfam.org.br/_img/artigos/A\%20democratiza\%C3\%A7\%C3\%A3o\%20do\%20c asamento.pdf.> Acesso em: 06 maio 2015.

Um novo direito Homoafetivo. Disponível em:

<http://www.mariaberenice.com.br/uploads/55_-_um_novo_direito_-

_direito_homoafetivo.pdf>.Acesso em: 25 mar. 2015.

União Homossexual: O Preconceito e a Justiça. $5^{\circ}$ ed. São Paulo: Revista dos Tribunais. 2005.

Família homoafetiva e seus direitos. Disponivel em:

$<$ http://www.mariaberenice.com.br/uploads/45_-

e-ISSN: 2525-9849| Minas Gerais | v. 2 | n. 1 | p. 146 - 168 | Jan/Dez. 2015. 
_a_fam\%EDlia_homoafetiva_e_seus_direitos.pdf>. Acesso em: 03 mar. 2015.

A homoafetividade e a justiça, 2010. Disponível em:

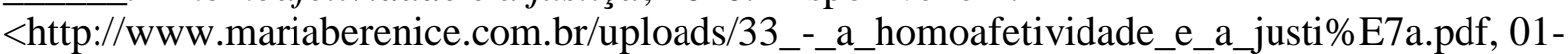
06-2012>. Acesso em : 12 abr. 2015.

FARIA, Cristiano Chaves. Código Civil para Concursos (CC) - 3a ed.: Rev., amp. e atualizada. 2015.

FARO, Julio Pinheiro; PESSANHA, Jackeline Fraga. O casamento civil homoafetivo e sua regulamentação no Brasil. Disponível em:

$<$ http://www.direitohomoafetivo.com.br/anexos/artigo/121_feaf705d0e755bbf2e1fb113aba7

48d4.pdf >. acesso em: 25 abr. 2015.

FERREIRA FILHO, Manoel Gonçalves. Direitos humanos fundamentais. São Paulo: Saraiva, 1995.

GOLIN, Célio; POCALY, Fernando Altair; RIOS, Roger Raupp (Orgs.). A Justiça e os direitos de gays e lésbicas: jurisprudência comentada. Porto Alegre: Editora Sulina, 2003.

GOMES, Orlando. Direito de família. Rio de Janeiro: Forense, 1998.

GRECO, Rogério. Curso de Direito Penal: parte geral. $2^{\mathrm{a}}$ ed., rev., ampl. e atual. Rio de Janeiro: Impetus. 2002.

HARBELE, Peter. Hermeneutica constitucional. Porto Alegre: Sergio Antonio Fabris, 1997.

LORDELLO, Josette Magalhães. A secularização do casamento no Brasil do século XIX: entre o Reino de Deus e o Reino dos Homens. Brasília: Editora UnB, 2002.

MADALENO, Rolf. Curso de direito de família. Rio de Janeiro: Forense, 2011.

MELLO, Marco Aurélio. A igualdade é colorida. Folha de S. Paulo, São Paulo, 19 ago. 2007.

MORAES, Alexandre. Direitos humanos fundamentais: teoria geral, comentários do art. $1^{\circ}$ ao $5^{\circ}$ da Constituição da Republica Federativa do Brasil. Doutrina e jurisprudência. 9 ed. São Paulo: Atlas, 2011.

MOTT, Luis. Homo-afetividade e direitos humanos. Homofobia: a violação dos direitos humanos dos gays, lésbicas e travestis no Brasil. San Francisco, USA: Editora IGLRHC, 1997. Disponível em:< http://www.scielo.br/pdf/ref/v14n2/a11v14n2.pdf> . Acesso em: 30 
mar. 2015.

Homossexualidade: mitos e verdades. Salvador: Editora GGB, 2003.

A revolução homossexual: o poder de um mito. Revista da USP, n. 49 (Dossiê Política \& Participação), 2001.

NERY JUNIOR, Nelson. Constituição Federal comentada e legislação constitucional. 4.ed.rev.atual e ampl. São Paulo: Revista dos Tribunais. 2013.

RANGEL, Rafael Calmon. O Judiciário e sua influencia na superação do preconceito contra a homoafetividade na américa do norte: reflexões sobre a possível repetição do fenômeno no Brasil. Disponível em:

<http://direitohomoafetivo.com.br/anexos/artigo/119_f7c01817ed20263e8f9f706afe15c5f2.p df>. Acesso em: 17 mar. 2015.

ROCHA, Marco Tulio. O conceito de família e suas implicações jurídicas: teoria sóciojurídica do Direito de família. São Paulo. Ed. Campus. 2009.

SARMENTO, Daniel. STF manifesta a favor da união homoafetiva. Disponível:

<http://www.conjur.com.br/2011-mar-26/grande-chance-stf-manifestar-favor-uniao-

homoafetiva>. Acesso em: 25 abr. 2015.

SULLIVAN, Andrew. Praticamente Normal: Uma Discussão sobre o Homossexualismo. São Paulo: Companhia das Letras, 1996.

TEIXEIRA, Jorge Luis. Ações afirmativas a favor das minorias e o principio da intervenção mínima. Disponível em:

<http://www.direitohomoafetivo.com.br/anexos/artigo/123_da14fdce8ccb5e8273113633cfcb 67df.pdf>. Acesso em: 05 abr. 2015.

VILLELA. João Baptista. Desbiologização da Paternidade. Revista da Faculdade de Direito da Universidade Federal de Minas Gerais, Belo Horizonte, $\mathrm{n}^{\circ}$ 21, 1979. 